地 震 第 2 輯

第 41 巻（1988）603-607頁

\title{
震源分布から見た四国における中央構造線
}

\author{
高知大学* 岡野 健 之 助 \\ 高知大学理学部附属高知地震観測所 ${ }^{* *}$ 木 村 昌 三 \\ (昭和 63 年 12 月 1 日受付; 平成 1 年 1 月 9 日受理)
}

\section{Characteristics of the Median Tectonic Line in Shikoku Inferred from the Focal Distribution of Microearthquakes}

\author{
Kennosuke OKano \\ Kochi University, Akebonocho 2-5-1, Kochi-shi, 780 \\ Shozo KimURA \\ Kochi Earthquake Observatory, Faculty of Science, Kochi University, \\ Asakura-honmachi 2-17-47, Kochi-shi, 780 \\ (Received December 1, 1988; Accepted January 9, 1989)
}

\begin{abstract}
In Shikoku, earthquakes in the crust show a vertically steplike distribution across the Median Tectonic Line (MTL). Namely, the upper and lower boundaries of the distribution in the southern side of MTL are shallower than those in the northern side of the line. Since crustal microearthquakes mainly occur in the granitic layer $\left(V_{p}=6.0 \mathrm{~km} / \mathrm{s}\right)$, the steplike distribution suggests a vertical dislocation in the granitic layer which was caused by uplifting of the southern part (Sanbagawa Metamorphic Belt) against MTL. On the other hand, most earthquakes in the mantle occur in the southern side of MTL in the central and eastern parts of Shikoku and occur in both the sides of MTL in the western part of Shikoku.
\end{abstract}

\section{§1. まえがき}

西南日本を外帯と内帯とに分ける中央構造線は世界で あ最大級の規模をむつ大構造線で，特に紀伊半島・四国 においては地質構造や地形の境界として明瞭である。こ れまでその生成の時期やメカニズムについて数多くの地 質学的研究が行われてきたにもかかわらず今もって定説 というべきものはみられない.

これはこの構造線の運動の形が，時代によりまた場所 によって異なるという複雑さが一因と思われる．四国に ついていえば，中央部においては際立った北落ちの断層 崖が見られるが，東部之西部では北側にそれぞれ阿讃山 地之高縄半島が上昇地形を示している．また横ずれ運動 は第四紀に入るまでは左ずれが卓越していたが，第四紀 後半に入ると右ずれの速度が著しく大きくなったとする かなり説得性のある研究結果 [岡田 (1973)] があるもの

昭和 63 年 4 月 8 日発表

* T780 高知市曙町 2 丁目 5-1

** 个780 高知市朝倉本町 2 丁目 17-47
の, この右ずれについては地質学的にも疑問が出されて いて [須鎗・阿子島 (1973)］必ずしも一般的に受け入れ られているとはいえない.

鉛直方向の断層運動については，地質学的観察からは 地表付近で低角ではあっても深部においては高角之する 考えが多い，しかしその断層運動がどの程度の深さにま で及んでいるかは想像の域をでないようである.

近年プレートテクトニクス論に基づいた解粕が行われ るようになり，例えば中央構造線はいわゆる断層という べきものではなく，フィリピン海プレートの沈み込み帯 が地表に姿を現したところではないかという考えが出さ れているし，また，四国と本州との相対運動によって生 じるトランスフォーム断層と解釈されてもいる[藤田 (1985)]. しかしいずれも納得のいくものではない.

一方地球物理学的には, 爆破地震動研究グループ (1981), 伊藤・他 (1982) によって, 中央構造線を横切る 測線について地殼構造の調查が行われ，構造線を境に階 段状の食い違いが認められているが，これは地表面に近 


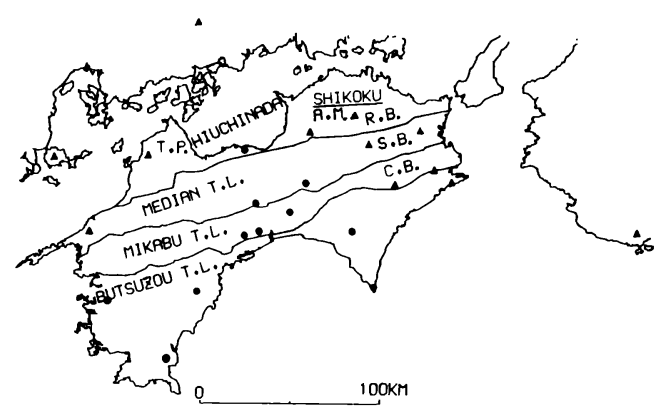

Fig. 1. Map showing the observation stations and the geological tectonic lines in and around Shikoku. Closed circles indicate stations of Kochi University and closed triangles Kyoto University and the University of Tokyo. The Median Tectonic Line (MTL) investigated in detail in the present study is located in the most northern region in Shikoku: A. M., Asan Mountains; R. B., Ryoke Belt; S. B., Sanbagawa Metamorphic Belt; C. B., Chichibu Belt; T.P., Takanawa Peninsula.

\section{い堆積岩層についてである.}

そこでさらに深い部分の情報を得ることができれば, その生成の議論に対する資料として多少なりとも役立つ あのと考えたが，弾性波探査法では深部についての速度 構造を現在の目的にかなうような精度で求めることは難 しい.それ故構造線に沿う地震の震源分布を詳細に調 へ，それと関連を持つであろう構造線の特徵を見ること にした.

\section{§ 2. $テ-夕$}

構造線に沿って発生する地震の震源の位置を精度よく 求めることが必要なので, 観測点は構造線に沿ってでき るだけ密に分布していることが望ましい. 第 5 次地震予 知計画によって, 四国東部には京都大学徳島地震観測所 が，中央部には高知大学高知地震観測所が，そして西部 には東京大学白木微小地震観測所が構造線の近くに観測 点を増設した. その一部についてはデータ交換が行われ ているので，四国中央部に匹敵する精度のよい震源決定 が可能となった. ただごく浅い地震についてはなお観測 点間の距離が大きいので確実性が劣る.

Fig. 1 に観測点の配置を示す. 使用したデー夕の期間 は 1982 年 7 月から 1987 年 12 月までであるが, 観測 点の設置の時期が同じではなく，また途中撤去したもの ああるので, 震源分布に用いた地震の選択は任意に行っ た.

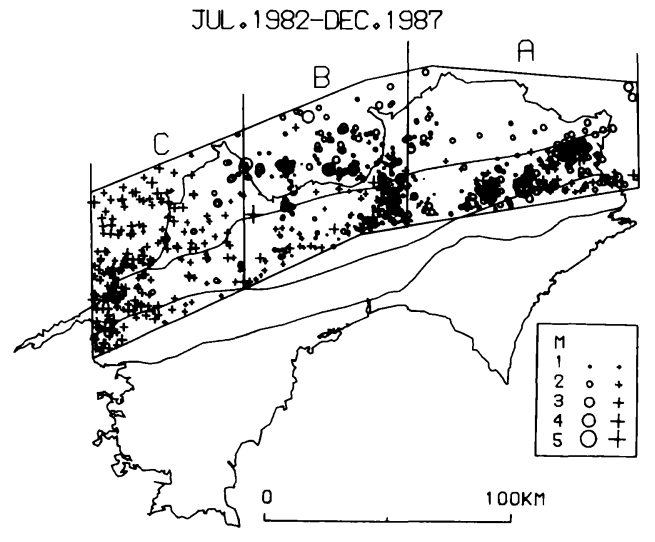

Fig. 2. Epicentral distribution of earthquakes occurring in the region along MTL from July 1982 to 1987 . Open circles and crosses indicate earthquakes with focal depths shallower and deeper than $23 \mathrm{~km}$, respectively. The region is divided into three of $\mathrm{A}$, $\mathrm{B}$ and $\mathrm{C}$ for the investigation of the focal depth distribution in each region.

\section{§3. 震源分布}

震源位置の決定には, 速度構造の影響を小さくするた めに前記の高知, 徳島, 白木の各観測網の震央に近い観 測点のデータのみを用いた。 その際震源時は $\mathrm{P}$ と $\mathrm{S}-\mathrm{P}$ 時間の関係から求め, 速度構造としては多層モデルを用 いて震源决定を行った [岡野・他(1985)]．今回の調查 に用いた中央構造線沿いの地域に発生した地震のみにつ いての震央分布を Fig. 2 (対象域は A, B , C の 3 領域に 分けた）に示す。この図から，震源分布が中央構造線と なんらかの関連を持っていることが推定されるものの, それは場所によって異なっていて必ずしも明瞭ではな w.

そこで震源の深さを $5 \mathrm{~km}$ 以浅, $5 \sim 8 \mathrm{~km}, 8 \sim 23 \mathrm{~km}$ (以上地款内地震), $23 \mathrm{~km}$ 以深（マントル地震）に分け て示したところ [Fig. 3 のそれぞれ (a), (b), (c), (d)], 両 者の関連がやや明らかになってきた。 すなわち，ごく浅 い地震 $(5 \mathrm{~km}$ 以浅) は三波川变成帯内に限られ, 構造線 の北側にはその発生が観測されていない. そして 5〜8 $\mathrm{km}$ の深さの地震はその活動は低いが構造線の北側にも 発生している. しかしそれは四国東部の阿讃山地と西部 の高縄半島に限られ，中央部の燧灘には全く発生してい ない.ところが震源がそれより深くなると $(8 \sim 23 \mathrm{~km})$, かえって燧灘で地震活動が高くなる.

深さ $23 \mathrm{~km}$ 以深のマントル地震は, 四国の中・東部 では中央構造線による制約が明らかに見られ，その南側 の高い活動に比べて北側における活動は極めて低い。一 
(a)

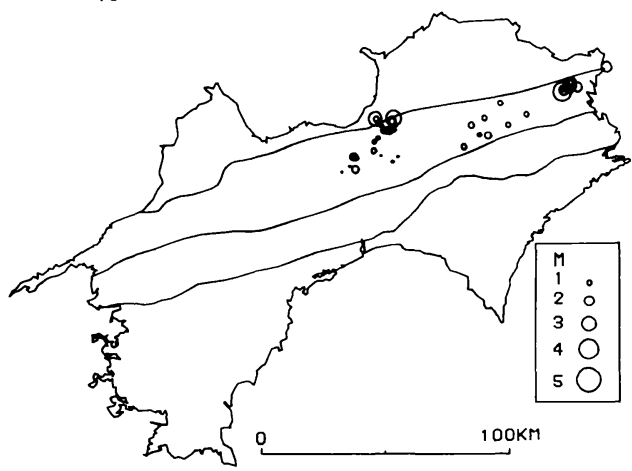

(c) JU. 1982-DEC.198? $(8<\mathrm{H} \leq 23 \mathrm{~km})$

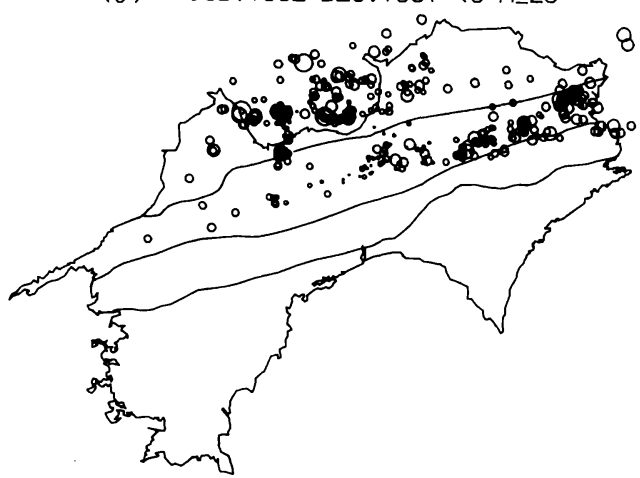

(b) JUL.1982-DEC.1987 (5<H $\leq 8 \mathrm{~km})$

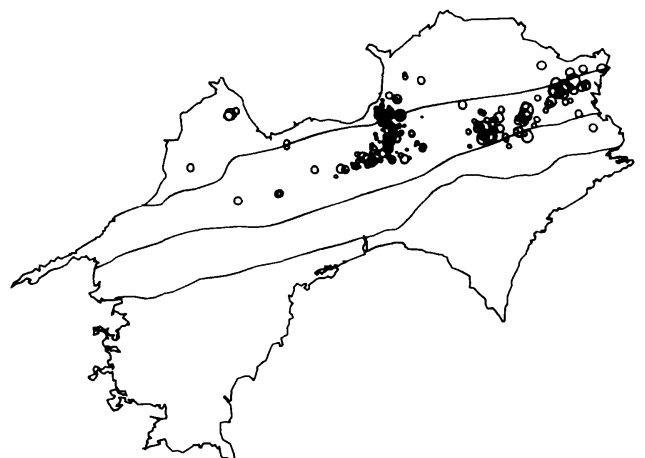

(d) JUL.1982-DEC.1987 (H>23k m)

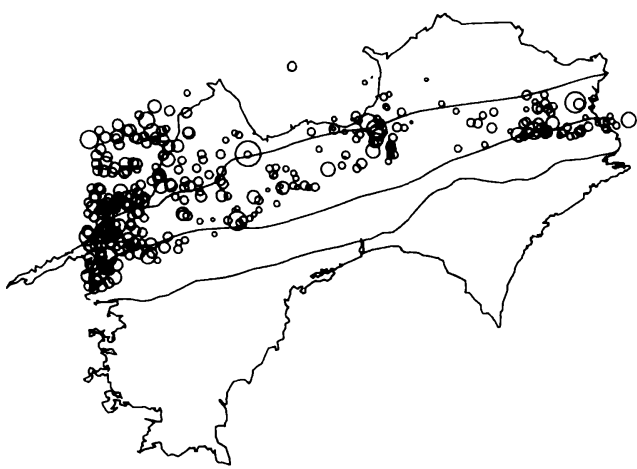

Fig. 3. Epicentral distributions for focal depth ranges of 0-5 km (a), 5-8 km (b), 8-23 km (c) and 23- km (d), respectively.

方西部においては中央構造線はマントル地震の活動にな んらの制約も与えていないように見える.

次に地震の深さ分布を示す (Fig. 4). この場合, 震源分 布に見られる場所による特徵の違いを参考にして, 東・ 中・西部の 3 区域（Fig. 2 に示した A, B, C 領域）に分 けて示した（Fig. 4 のそれぞれ A, B C C). その際構造線 の走向のわずかな違いが各々の深さ分布図に微妙に影響 するので, それぞれ最も適当と考えられる走向を選ん だ.

\section{§4. 考察}

四国地方の震源分布が地下構造と密接な関連を持つこ とは，筆者らがしばしば指摘してきた[岡野・他 (1983), 木村・川谷 (1987), 岡野 (1988)]. 例えば深さが $5 \mathrm{~km}$ より浅い地震は, 北の中央構造線と南の御荷鉾構 造線にはさまれた三波川変成帯に主として発生している が、これはいわゆる $6.0 \mathrm{~km} / \mathrm{s}$ 層 (花崗岩質層) が, 三波 川帯では南の秩父帯に比べてかなり浅い所にまで上がっ ていることを示しているのであろう。それ故中央構造線
より北側の地域でこのごく浅い地震が発生せずにそれよ り深い地震が発生することは，北側の地域においてもま た $6 \mathrm{~km} / \mathrm{s}$ 層の上面が秩父帯におけると同じぐらいの深 さにあると考えてよいのであろう，従って中央構造線を 境とした階段状の構造が推定される (Fig. 4)。これは爆 破地震動研究グループ (1981) によって堆積岩層 $\left(V_{p}=\right.$ $4.8 \mathrm{~km} / \mathrm{s}$ ) に認められた階段状の食い違いとほぼ一致し ているので，この食い違いは少なくとも $6 \mathrm{~km} / \mathrm{s}$ 層にま では達しているあのと解釈できる.

また, $5 \sim 8 \mathrm{~km}$ の深さの地震か阿讃山地と高縄半島に 見られるのに燧灘には皆無ということは，岡野・他 (1985) が先に指摘した海水の浸透による効果を示して いるのであって, 構造の相違によるものではないと思わ れる. 深さが 8〜23 km の地款内地震は中央構造線と関 係なく四国全域で発生しているようである. しかし遂灘 における活動はかなり高く，中央構造線の南側の低活動 に比へて対照的で，その分布は中国地方まで続いている ようである [岡野 (1988)] が，やはり中央構造線の影響 を受けているのであろうか. 
A

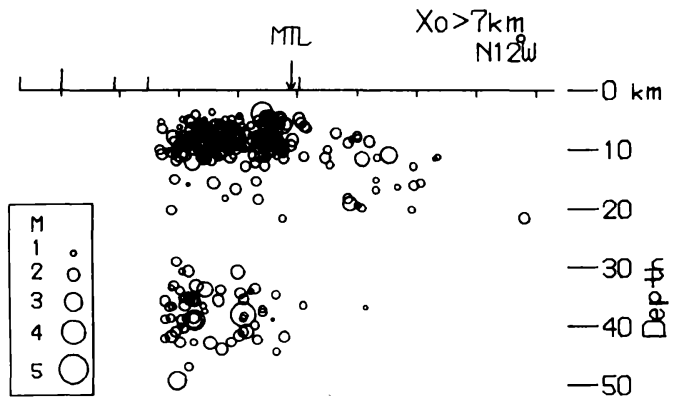

C

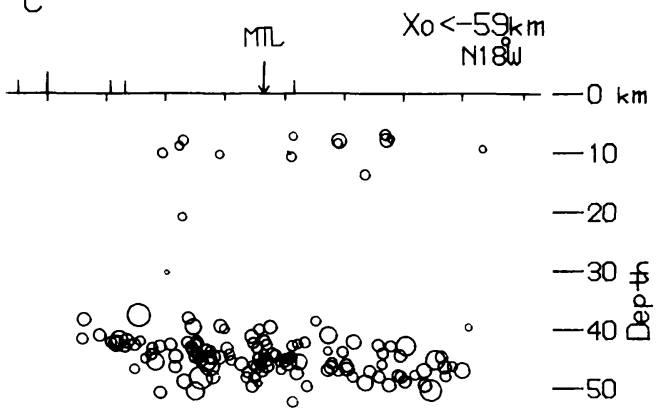

次に四国の中・東部域のマントル地震については，中 央構造線が震源分布の北限として位置していることは疑 いのないところであるが，構造線の北側に全く地震が発 生していない訳ではなく，北傾斜の震源分布の延長上に 発生が認められるので，先に述べた $5 \mathrm{~km}$ 以浅の地震の 場合のような構造上の境界になっているとは考えにく い.

このことは西部における分布からも考えられることで ある. この地域では約 8〜10 度の北下がりの分布が中央 構造線を越えてかなり北側まで延びている，西部と中・ 東部におけるこの違いは現在解釈のしようがない，ただ 中・東部に比べてかなり活発な西部における地震活動 は，豊後水道から九州へと入るやや深発地震帯の活動に 組み入れられるべきもので，中・東部の活動とやや違っ た性格を持つのであろうか。

以上のように中央構造線は少なくとも上部地殻におい ては構造的不連続の境界をなしているのであろう。これ は南の三波川变成帯が北の領家帯に対して相対的に上昇 (2〜3 km) した結果と考えられる。むっとも東部の阿讃 山地之西部の高縄半島の地形からは，北側地域の隆起を 考えたくなるが，震源分布からは少なくとも中・東部に ついては構造線の南側上昇とした方が妥当である．西部 については浅い地震の活動が極端に低いので断定できな いが，東・中部からの連続した地質構造が西部で絶たれ
B

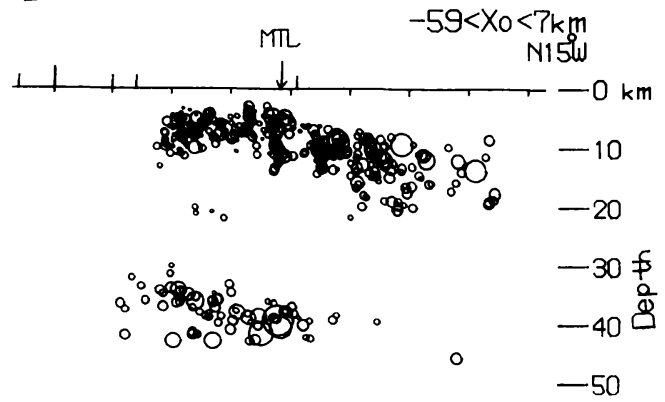

Fig. 4. Hypocentral distributions of earthquakes in $\mathrm{A}, \mathrm{B}$ and $\mathrm{C}$ regions in Fig. 2 onto vertical planes striking in directions of $\mathrm{N} 12^{\circ} \mathrm{W}(\mathrm{A}), \mathrm{N} 15^{\circ} \mathrm{W}(\mathrm{B})$ and $\mathrm{N} 18^{\circ} \mathrm{W}(\mathrm{C})$, respectively. $\mathrm{X}_{0}$ is a distance measured from WMY observation point. The seismic data from April 1985 to 1987 are used for the focal distribution in $\mathrm{C}$ region only.

るのでなければ，やはり同様な特徵を持つと考えてよい のではなかろうか．この場合この食い違い面は震源の深 さ分布加見て当然鉛直に近いと考えられる. しかし地 質学的観察からはスラストを推定する場合が多く，この 種の不一致はしばしば経験するところである。これは地 質学の観察が地表付近であることが原因であるが，その ことを頭に入れて深さ分布を見ると，分布に見られる上 下のずれ境界面は必ずしも地表の構造線の位置と一致せ ず，やや北にずれていることは何か意味を持っているの かもしれない，地表に観察されるスラストは地表直下だ けであって，深く入ると鉛直に近くなるとする地質学的 推測と合っているようにも思われる.

上部地殼におけるこのずれ境界面の下方への延長は, 中・東部においてはマントル地震の分布の北限とほぼ一 致するので, 境界面がマントルまで続いていると考える のが普通であろう．すると中央構造線はマントルにまで 入る深部断裂ということになる。しかし現在のマントル 地震の深さ分布からは上下のずれを見出すことはできな いので，断裂が地下深部まで達しているかどうかはわか らない.

次に最大起震力の方向が中央構造線を境にして変化す るかどうかを調べてみた (Fig. 5) が，そのようなことは なく地款内地震はほぼ東西方向, マントル地震はほぼ南 北方向という特徵には变化が見られないので, 西南日本 
1979-1987 (M>1.9)
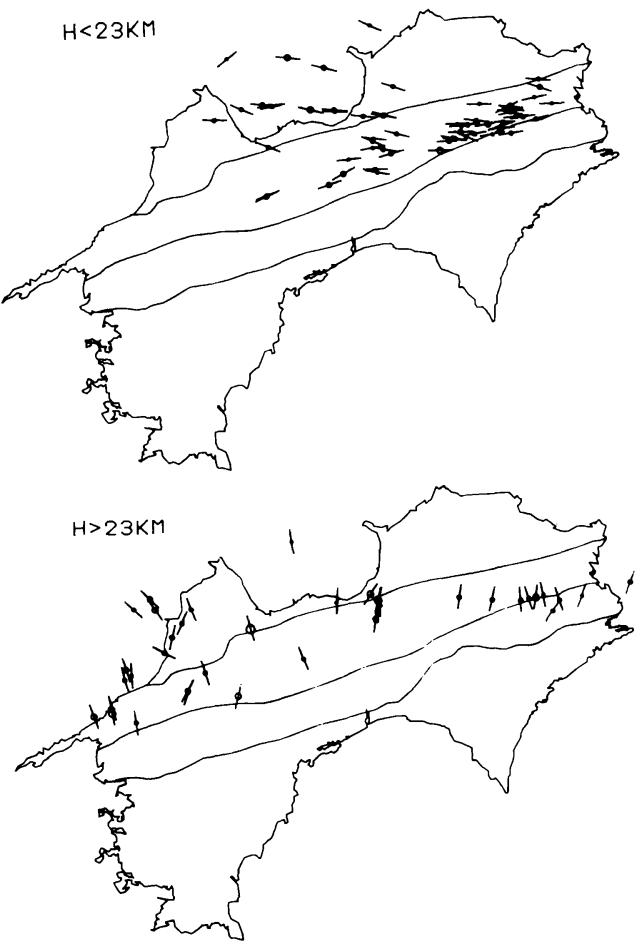

Fig. 5. Distribution of the horizontal direction of maximum pressure axes for earthquakes occurring in the neighbourhood of MTL. Earthquakes with magnitudes greater than 1.9 for the period of 1979-1987 are used. Earthquakes shown in the upper and lower figures correspond to those with focal depths shallower and deeper than $23 \mathrm{~km}$, respectively.

に加わる地款応力は中央構造線の影響を受けていない

し，また与えてもいないと考えてさしつかえないであろ う.さらに中央構造線に沿ってそのごく近傍に起こる地 震の初動分布から得られる最大主圧力の方向むまたそれ ぞれ東西, 南北であって, 従って構造線がすべって起 こったと考えられる地震は観测されなかった。

\section{§5. あとがき}

ここで得られた四国地方における中央構造線と震源分 布との関連が構造線の深部を考える際の情報として役に 立てば幸いである．微小地震の観測データがかなり集積 されたとはいえ細かい点を議論するためにはまだまだ不 充分である. 特に浅い地震の震源を精度よく求めるため にはその深さ程度の相互距離を持った観湘網が必要であ る.しかも充分な量のデータを得るためには長い年月を 必要とする.このため現在の常時観測網によって行うこ とは困難であるし，臨時観測によることはさらに難し い.

なお構造線の構造を知るためには速度構造を調べるこ とがより直接的ではあるが，深部についての速度を高い 精度で求めることは極めて困難なので震源分布に頼らざ るを得ない。

この研究を行うにあたって京都大学徳島地震観測所お よび東京大学白木微小地震観測所のデータを使用させて いただいた。厚く御礼申し上げます。

\section{文献}

爆破地震動研究グループ，1981，爆破地震動観測による 四国東北部の地殼構造の研究，昭和 $54 \cdot 55$ 年度文部 省科学研究費 総合研究 (A)434020, 1-31.

藤田和夫, 1985, 変動する日本列島, 岩波書店（岩波新 書), 200-206.

伊藤 潔・吉井敏克 - 浅野周三・佐々木嘉三・伊神 煇, 1982, 家島・鳥形山爆破地震動観測による四国地 域の地款構造, 地震 2, 35, 377-391.

木村昌三・川谷和夫, 1987, 四国中央部における震源分 布 (1967・4～1986), 地震学会講演予稿集, No. 2, 104.

岡田篤正，1973，中央構造線の第四紀断層運動につい $\tau$, 中央構造線, 東海大学出版会, 49-85.

岡野健之助, 1988, 四国の地震, 土佐出版社. 岡野健之助・木村昌三・許斐 直, 1983 , 四国地方の震 源分布と地質構造線との関連, 地震 $2,36,23-29$. 岡野健之助・木村昌三・許斐 直・中村正夫, 1985, 四 国および周辺地域の震源分布，地震 2, 38, 93-103.

須鎗和巳・阿子島 功, 1973, 四国島の中央構造線の新 期の活動様式, 中央構造線, 東海大学出版会, 179189. 